\title{
Pumpkin Growth, Flowering, and Fruiting Response to Nitrogen and Potassium Sprinkler Fertigation in Sandy Soil
}

\author{
John M. Swiader ${ }^{1}$, Stanley K. Sipp ${ }^{2}$, and Ronald E. Brown ${ }^{3}$ \\ Department of Horticulture, University of Illinois, Urbana, IL 61801
}

\begin{abstract}
Additional index words. Cucurbita moschata, chemigation, nutrition, anthesis
Abstract. Field studies were conducted in 1987 and 1988 to determine the effect of various sprinkler-applied N-K fertigation treatments and $196 \mathrm{~N}-280 \mathrm{~K}\left(\mathrm{~kg} \cdot \mathrm{ha}^{-1}\right)$ dry-blend application on pumpkin (Cucurbita moschata Poir.) flower development, fruit set, vine growth, and marketable yield response in a Plainfield sand. The number of male and female flowers that reached anthesis by 72 days after seeding (DAS) was highest with either 112N-112K or 112N-224K fertigation. Fertigation using either $56 \mathrm{~N}-112 \mathrm{~K}$ or $168 \mathrm{~N}-224 \mathrm{~K}$ delayed the start of flowering and reduced the total number of male and female flowers produced by 72 DAS. Fruit set decreased at the low $\mathrm{N}-\mathrm{K}$ fertigation rate $(56 \mathrm{~N}-112 \mathrm{~K})$, but otherwise was unaffected by $\mathrm{N}-\mathrm{K}$ fertility regime. Vine dry weight and stem elongation increased as the $\mathrm{N}$ fertigation rate increased, with relatively little effect from fertigated $\mathrm{K}$. There was no field indication of excessive vegetative growth in any of the fertigation treatments. Highest yields of early set marketable fruit (pumpkins that set before 65 DAS), and total marketable yields were obtained with fertigation of $112 \mathrm{~N}$, in combination with either $112 \mathrm{or} 224 \mathrm{~kg} \cdot \mathrm{ha}^{-1}$ fertigated K. Usable green and cull fruit production increased with increasing $\mathrm{N}-\mathrm{K}$ fertigation rate. Dry-blend application of 196N$280 \mathrm{~K}$ decreased early and total yields significantly. The results showed that sprinkler-applied 112N-112K split into five fertigations during the growing season (supplemented with a preplant dry-blend application of $28 \mathrm{~N}-56 \mathrm{~K}$ ) produced high yields without compromising early fruit maturity.
\end{abstract}

Illinois leads the United States in the production of processing pumpkins, with the commercial acreage ( $\approx 4000$ ha) evenly distributed between irrigated production on sandy soils, used for the early crop, and dryland culture on heavy-textured soils, used for the main-season and late crops. On sandy soils, it is becoming common practice to apply most of the $\mathrm{N}$ and $\mathrm{K}$ fertilizer in several increments during the growing season with the irrigation water, using overhead center-pivot sprinkler systems, in addition to a small amount of granular, or dry-blend, fertilizer applied before planting.

Commonly referred to as fertigation or chemigation, application of fertilizer with irrigation water has several inherent advantages over conventional dry-blend fertilization for crop production on coarse-textured soils, including lower fertilizer inputs, reduced nutrient leaching, and flexibility in scheduling to meet crop demands (Rehm and Wiese, 1975; Saffigna and Keeney, 1977; Watts and Martin, 1981). For pumpkin production, in particular, fertigation can be a very accurate method for uniform applications of inseason $\mathrm{N}$ and $\mathrm{K}$ during early fruit development, when $\mathrm{N}$ and $\mathrm{K}$ requirements are highest (Swiader, 1985), and when sidedressing of granular fertilizer is not possible after vines start to run and fill in between the rows. However, when fertigating $\mathrm{N}$ and $\mathrm{K}$, pumpkin growers frequently complain of delayed fruit development. Field observations tend to implicate excessive vegetative growth and inconsistent flowering as causal factors, although there are no data to support this.

Research with other cucurbits has shown an interaction be-

Received for publication 4 May 1993. Accepted for publication 25 Aug. 1993. This work was supported by Project 65-332 of the Illinois Agricultural Experiment Station, University of Illinois at Urbana-Champaign, and the Nestle Food Company. We thank Douglas Scheirer of the Nestle Food Company for his technical assistance. The cost of publishing this paper was defrayed in part by the payment of page charges. Under postal regulations, this paper therefore must be hereby marked advertisement solely to indicate this fact.

${ }^{1}$ Associate professor.

${ }^{2}$ Associate agronomist.

${ }^{3}$ Graduate research assistant. tween $\mathrm{N}$ fertilization and sprinkler irrigation, with an optimum application of $\mathrm{N}$ for a given level of irrigation (Flocker et al., 1965; Smittle and Threadgill, 1982). In previous work with pumpkins on irrigated sand using dry-blend fertilizer application, estimated maximum yields occurred at $225 \mathrm{~kg} \mathrm{~N} / \mathrm{ha}$, although at $\mathrm{N}$ rates $>134$ $\mathrm{kg} / \mathrm{ha}^{-1}$ the relative yield response was small (Swiader et al., 1988). Furthermore, fruit set and harvest were delayed 8 and 9 days, respectively, from application of $202 \mathrm{~kg} \mathrm{~N} / \mathrm{ha}$, thereby offsetting the small yield increase at higher $\mathrm{N}$ rates.

Little information, if any, is available regarding $\mathrm{N}$ and $\mathrm{K}$ fertigation requirements for pumpkins. Fertigation practices vary widely, with growers applying up to $150 \mathrm{~kg} \mathrm{~N} / \mathrm{ha}$ and $200 \mathrm{~kg} \mathrm{~K} / \mathrm{ha}$ to the crop. The objective of this study was to determine the rates of fertigated $\mathrm{N}-\mathrm{K}$ required for high early and total yields of pumpkins in sandy soil. The effect of $\mathrm{N}-\mathrm{K}$ fertigation on pumpkin vine growth, flower production, and fruit development was also evaluated. Since some production areas still use considerable granular fertilization, an additional objective was to compare dryblend application with $\mathrm{N}-\mathrm{K}$ fertigation for its effect on pumpkin growth, flowering, and yield response.

\section{Materials and Methods}

Field studies were conducted in 1987 and 1988 at the Illinois River Valley-Univ. of Illinois Sand Field in Kilbourne, Ill. The soil at the site was a Plainfield sand (sandy, mixed, mesic Typic Udipsamment), characterized by low organic-matter content $(0.5 \%)$ and low nutrient-holding capacity (CEC $2.5 \mathrm{meq} / 100 \mathrm{~g}$ ). During the fall before each study, the site was seeded with a rye (Secale cereale L.) cover crop, which was plowed into the soil in April. In Fall 1986, ground calcitic limestone $\left(6 \mathrm{t} \cdot \mathrm{ha}^{-1}\right)$ was broadcast and incorporated in the upper $20 \mathrm{~cm}$ of soil to adjust the soil $\mathrm{pH}$ to $\approx 6.8$. One week before planting, all plots were fertilized with $\mathrm{P}$ at 56 $\mathrm{kg} \cdot \mathrm{ha}$ as concentrated-superphosphate, and $\mathrm{Mg}$ at $22 \mathrm{~kg} \cdot \mathrm{ha}^{-1}$ as $\mathrm{MgSO}_{4}$.

Each year, treatments included three $\mathrm{N}-\mathrm{K}$ fertigation combinations and one dry-blend $\mathrm{N}-\mathrm{K}$ application, based on current com- 
Table 1. Pumpkin N-K fertigation and dry-blend treatment regimes (rates and timings) in 1987 and 1988.

\begin{tabular}{|c|c|c|c|c|c|c|c|c|}
\hline \multirow[b]{2}{*}{ Fertilizer timing } & \multicolumn{4}{|c|}{1987} & \multicolumn{4}{|c|}{1988} \\
\hline & \multicolumn{3}{|c|}{ Fertigation } & Dry-blend & \multicolumn{3}{|c|}{ Fertigation } & Dry-blend \\
\hline & \multicolumn{8}{|c|}{$\bar{N}-K \overline{\left(k g \cdot h a^{-1}\right)}$} \\
\hline Preplant & --- & --- & --- & $168.0-256.0$ & --- & --- & --- & $168.0-256.0$ \\
\hline \multicolumn{9}{|l|}{ Days after seeding } \\
\hline 15 & $8.4-22.4$ & $16.8-11.2$ & $16.8-22.4$ & --- & $16.8-22.4$ & $16.8-33.6$ & $33.6-33.6$ & --- \\
\hline 25 & $8.4-22.4$ & $16.8-11.2$ & $16.8-22.4$ & $28.0-24.0$ & $16.8-22.4$ & $16.8-33.6$ & $33.6-33.6$ & $28.0-24.0$ \\
\hline 35 & $8.4-22.4$ & $16.8-11.2$ & $16.8-22.4$ & --- & $16.8-22.4$ & $16.8-33.6$ & $33.6-33.6$ & --- \\
\hline 65 & $15.4-22.4$ & $30.8-11.2$ & $30.8-22.4$ & --- & $30.8-22.4$ & $30.8-33.6$ & $33.6-33.6$ & --- \\
\hline 75 & $15.4-22.4$ & $30.8-11.2$ & $30.8-22.4$ & --- & $30.8-22.4$ & $30.8-33.6$ & $33.6-33.6$ & - \\
\hline 85 & --- & --- & --- & --- & --- & $0.0-56.0$ & $0.0-56.0$ & --- \\
\hline Total $^{\mathrm{z}}$ & $56-112$ & $112-56$ & $112-112$ & $196-280$ & $112-112$ & $112-224$ & $168-224$ & $196-280$ \\
\hline
\end{tabular}

${ }_{\mathrm{z}}$ In addition, all fertigated treatments received a preplant dry-blend application of $28 \mathrm{~N}-56 \mathrm{~K} \approx 10$ days before seeding.

mercial practices for granular fertilization in sandy soil (Table 1). Individual treatment plots comprised $166 \mathrm{~m}^{2}(18.2 \times 9.1 \mathrm{~m})$, arranged in a randomized complete-block design with three replications in 1987, and four replications in 1988. Fertigated $\mathrm{N}$ and $\mathrm{K}$ were applied as urea-ammonium nitrate and $\mathrm{KCl}$, respectively, using a combination portable-pipe and overhead sprinkler system fitted with Venturi-type fertilizer injectors. Fertigation applications were made by injecting measured volumes of the appropriate fertilizer mixture into an $0.8-\mathrm{cm}$ irrigation line running down the center of each plot. To avoid $\mathrm{N}$ and $\mathrm{K}$ accumulation, a minimum of $10 \mathrm{~min}$ of irrigation rinse followed each application. Dry-blend $\mathrm{N}$ and $\mathrm{K}$ was applied as $\mathrm{NH}_{4} \mathrm{NO}_{3}$ and $\mathrm{KCl}$. All preplant dry-blend $\mathrm{N}$ and $\mathrm{K}$ was broadcast and disked into the top $30 \mathrm{~cm}$ of soil. Inseason dry-blend $\mathrm{N}$ and $\mathrm{K}$ was banded on the soil surface $\approx 15 \mathrm{~cm}$ from the plants and lightly incorporated into the soil. During fertigation of $\mathrm{N}$ and $\mathrm{K}$, plots that received the dry-blend treatment were irrigated at the same time and rate as fertigated plots. Additional irrigation was applied to all plots to provide a total (including rainfall) of $3.8 \mathrm{~cm}$ of water per week.

In May of each year, 'Libby-Select' pumpkin was seeded by hand at $0.46-\mathrm{m}$ intervals in double rows $1.5 \mathrm{~m}$ apart (spaced on either side of the irrigation line) and $12.2 \mathrm{~m}$ long in the center of each plot. When seedlings developed two true leaves, hills were thinned to one plant, resulting in a stand of 54 plants per plot, or $\approx 7300$ plants/ha. (Note that this approximation is based on an area of $12.2 \mathrm{~m} \times 6.1 \mathrm{~m}$ and disregards a buffer zone, $3.0 \mathrm{~m}$ on each end and $1.5 \mathrm{~m}$ on each side, which was used to limit the effects of plants in neighboring plots.)

Beginning with anthesis of the first flowers, and continuing until 72 days after seeding (DAS), all newly emerging male and female flowers were marked with designated colored plastic flags inserted in the ground next to each inflorescence, and the date was recorded. To evaluate the effect of the various treatments on earliness of flowering, node number and days to anthesis of the first five male and female flowers appearing in each plot were determined. Tissue samples with the first fully expanded leaf nearest the growing tip were collected from eight plants in each plot for mineral analysis 46,72 , and 90 DAS. In addition, four randomly selected plants were harvested from each plot at 72 DAS and assayed for vine node count, stem length, and total shoot dry weight.

All fruits were harvested by hand in a once-over operation when it was estimated that one-half of the plots had reached commercial maturity, as indicated by color change from green to tan in $75 \%$ of the pumpkins. The number and total weight of marketable and cull fruit were recorded. Marketable yield data were divided into three categories based on fruit maturity: early-set fruit (fruits that had set by $64 \mathrm{DAS}$ ); mid-season-set fruit (fruits that had set after $64 \mathrm{DAS}$, and which were ripe at harvest); and usable-green fruit (immature fruits $>15 \mathrm{~cm}$ in diameter that were suitable for mechanical harvest and processing). Fruits $<15 \mathrm{~cm}$ in diameter were considered culls, in addition to any split or unusable larger fruits. Plastic flags without an accompanying fruit were counted as female flowers that failed to set fruit.

Plant samples were dried in a forced-air oven at $70 \mathrm{C}$ for $\approx 48 \mathrm{~h}$. Total $\mathrm{N}$ was determined using a modified micro-Kjeldahl digestion procedure (Nelson and Sommers, 1980), in conjunction with an indolephenol-blue colorimetric assay (Cataldo et al., 1974). Tissue $\mathrm{K}$ concentration was measured using flame emission photometry following $\mathrm{HNO}_{3}-\mathrm{H}_{2} \mathrm{O}_{2}$ digestion. Soluble solids were measured with a refractometer for three randomly selected fruit per plot for each maturity period. The data were evaluated by analysis of variance. The time course of daily flower development up to 72 DAS was characterized in each of the $\mathrm{N}-\mathrm{K}$ treatments by regression analysis using the GLM procedure (Spector et al., 1985).

\section{Results and Discussion}

Flower development. Significant differences in pumpkin flower production were found among fertigation treatments in both years (Table 2). In 1987, the number of male and female flowers that reached anthesis by 72 DAS was highest with $112 \mathrm{~N}-112 \mathrm{~K}$ fertigation, intermediate with $112 \mathrm{~N}-56 \mathrm{~K}$, and lowest with $56 \mathrm{~N}-112 \mathrm{~K}$, where plants averaged less than one female flower each. In 1988, flower production was similar in the $112 \mathrm{~N}-112 \mathrm{~K}$ and $112 \mathrm{~N}-224 \mathrm{~K}$ treatments, but decreased significantly at the high $\mathrm{N}$ fertigation rate $(168 \mathrm{~N}-224 \mathrm{~K})$. Increasing $\mathrm{K}$ fertigation rate from 56 to $112 \mathrm{~K}$, in conjunction with $112 \mathrm{~N}$, increased male flower production in 1987, but otherwise there was relatively little effect of K fertigation on flower development up to 72 DAS. In both years, male and female flower production was greater with $112 \mathrm{~N}-112 \mathrm{~K}$ fertigation than with the dry-blend application. There were no differences between treatments in male to female flower ratio, with plants producing $\approx 10$ male flowers to each female flower.

The earliest appearance of male and female flowers was in the $112 \mathrm{~N}-112 \mathrm{~K}$ and $112 \mathrm{~N}-224 \mathrm{~K}$ fertigation treatments (Table 2). Days to first male and female flowers increased at both high $(168 \mathrm{~N}-224 \mathrm{~K})$ and low $\mathrm{N}$ fertigation $(56 \mathrm{~N}-112 \mathrm{~K})$ rates. Compared to the $112 \mathrm{~N}-112 \mathrm{~K}$ treatment, initial anthesis of male and female flowers was delayed 6.5 and 7 days, respectively, with $168 \mathrm{~N}-$ 224K, and 9.8 and 9.0 days, respectively, with 56N-112K. Node number of first female flowers also increased at the high fertigation 
Table 2. Effect of N-K fertilization regime on pumpkin flower response and fruit set through 72 days after seeding (DAS) in 1987 and 1988.

\begin{tabular}{|c|c|c|c|c|c|c|c|c|}
\hline \multirow[b]{3}{*}{ Characteristic } & \multicolumn{4}{|c|}{1987} & \multicolumn{4}{|c|}{1988} \\
\hline & \multicolumn{3}{|c|}{$\begin{array}{c}\mathrm{N}-\mathrm{K} \\
\text { fertigation } \\
\left(\mathrm{kg} \cdot \mathrm{ha}^{-1}\right)\end{array}$} & \multirow{2}{*}{ 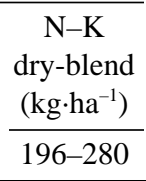 } & \multicolumn{3}{|c|}{$\begin{array}{c}\mathrm{N}-\mathrm{K} \\
\text { fertigation } \\
\left(\mathrm{kg} \cdot \mathrm{ha}^{-1}\right)\end{array}$} & \multirow{2}{*}{$\begin{array}{c}\text { N-K } \\
\text { dry-blend } \\
\left(\mathrm{kg} \cdot \mathrm{ha}^{-1}\right) \\
196-280\end{array}$} \\
\hline & $56-112$ & $112-56$ & $112-112$ & & $112-112$ & $112-224$ & $168-224$ & \\
\hline Male flowers/plant (no.) & $9.4 c^{z}$ & $23.2 \mathrm{~b}$ & $31.1 \mathrm{a}$ & $17.7 \mathrm{~b}$ & $29.5 \mathrm{a}$ & $33.2 \mathrm{a}$ & $21.8 \mathrm{~b}$ & $20.2 \mathrm{~b}$ \\
\hline Days to first male flower (no.) & $58.3 \mathrm{a}$ & $50.0 \mathrm{~b}$ & $48.5 \mathrm{~b}$ & $52.0 \mathrm{ab}$ & $47.0 \mathrm{a}$ & $47.5 \mathrm{a}$ & $53.5 \mathrm{a}$ & $51.0 \mathrm{a}$ \\
\hline Nodes to first male flower (no.) & $8.5 \mathrm{a}$ & $7.5 \mathrm{a}$ & $7.5 \mathrm{a}$ & $10.0 \mathrm{a}$ & $8.3 \mathrm{a}$ & $7.5 \mathrm{a}$ & $10.0 \mathrm{a}$ & $9.8 \mathrm{a}$ \\
\hline $\begin{array}{l}\text { Relative male flowering rate } \\
\text { (flowers/plant/day })^{\mathrm{y}}\end{array}$ & $0.64 \mathrm{c}$ & $1.05 \mathrm{ab}$ & $1.27 \mathrm{a}$ & $0.91 \mathrm{~b}$ & $1.14 \mathrm{ab}$ & $1.30 \mathrm{a}$ & $1.11 \mathrm{ab}$ & $0.98 \mathrm{~b}$ \\
\hline Female flowers/plant (no.) & $0.95 \mathrm{c}$ & $2.59 \mathrm{ab}$ & $2.91 \mathrm{a}$ & $1.84 \mathrm{~b}$ & $3.38 \mathrm{a}$ & $3.01 \mathrm{a}$ & $2.11 \mathrm{~b}$ & $1.88 \mathrm{~b}$ \\
\hline Days to first female flower (no.) & $60.0 \mathrm{a}$ & $51.8 \mathrm{~b}$ & $51.0 \mathrm{~b}$ & $53.0 \mathrm{~b}$ & $49.0 \mathrm{~b}$ & $50.0 \mathrm{~b}$ & $56.0 \mathrm{a}$ & $52.8 \mathrm{ab}$ \\
\hline Nodes to first female flower (no.) & $12.0 \mathrm{a}$ & $11.0 \mathrm{a}$ & $10.3 \mathrm{a}$ & $13.0 \mathrm{a}$ & $11.0 \mathrm{~b}$ & $10.5 \mathrm{~b}$ & $16.0 \mathrm{a}$ & $14.3 \mathrm{ab}$ \\
\hline $\begin{array}{l}\text { Relative female flowering rate } \\
\text { (flowers/plant/day) })^{\mathrm{y}}\end{array}$ & $0.07 \mathrm{~b}$ & $0.12 \mathrm{a}$ & $0.13 \mathrm{a}$ & $0.09 \mathrm{ab}$ & $0.14 \mathrm{a}$ & $0.13 \mathrm{a}$ & $0.13 \mathrm{a}$ & $0.09 \mathrm{~b}$ \\
\hline Female flower fruit set $(\%)$ & $40.3 \mathrm{~b}$ & $53.5 \mathrm{a}$ & $51.9 \mathrm{a}$ & $57.8 \mathrm{a}$ & $53.3 \mathrm{a}$ & $52.8 \mathrm{a}$ & $58.4 \mathrm{a}$ & $60.2 \mathrm{a}$ \\
\hline Daily male : female flower ratio & $9.1 \mathrm{a}$ & $8.9 \mathrm{a}$ & $10.7 \mathrm{a}$ & $11.0 \mathrm{a}$ & $9.1 \mathrm{a}$ & $10.5 \mathrm{a}$ & $10.7 \mathrm{a}$ & $11.3 \mathrm{a}$ \\
\hline
\end{tabular}

${ }^{\mathrm{z}}$ For each year, mean separation within rows by LSD at $P=0.05$.

${ }^{\mathrm{y}}$ For the period starting at initial anthesis and continuing through 72 DAS.

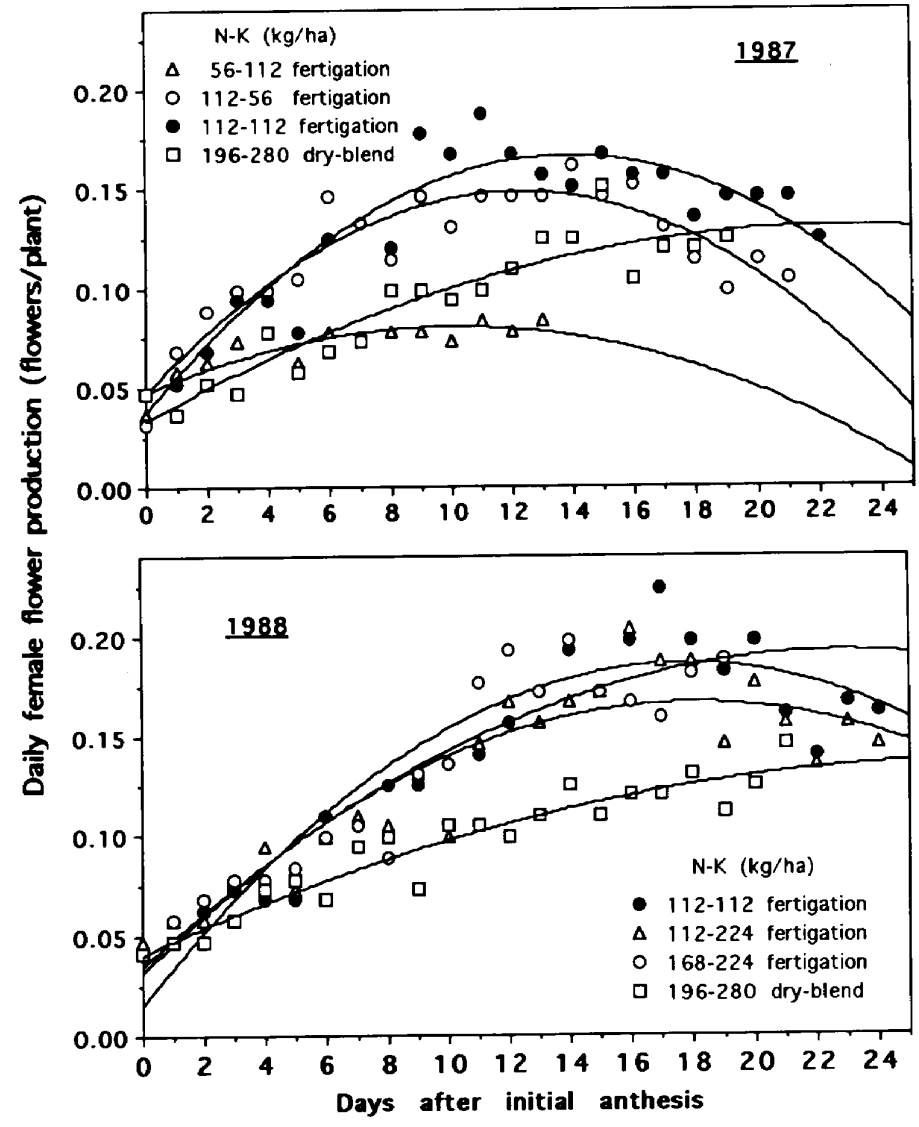

Fig. 1. Relationship between daily female flower production and days after initial anthesis, in response to various $\mathrm{N}-\mathrm{K}$ fertilization regimes in 1987 and 1988. Regression equations for the lines shown were as follows: $1987-56 \mathrm{~N}-112 \mathrm{~K}$, y $=0.047+0.0068 \mathrm{x}-0.00035 \mathrm{x}^{2}\left(R^{2}=0.28\right) ; 112 \mathrm{~N}-56 \mathrm{~K}, \mathrm{y}=0.049+0.0163 \mathrm{x}-$ $0.00067 \mathrm{x}^{2}\left(R^{2}=0.47\right) ; 112 \mathrm{~N}-112 \mathrm{~K}, \mathrm{y}=0.041+0.0178 \mathrm{x}-0.00066 \mathrm{x}^{2}\left(R^{2}=0.41\right)$; $196 \mathrm{~N}-280 \mathrm{~K}, \mathrm{y}=0.033+0.0086 \mathrm{x}-0.0002 \mathrm{x}^{2}\left(R^{2}=0.62\right) ; 1988-112 \mathrm{~N}-112 \mathrm{~K}, \mathrm{y}$ $=0.014+0.0198 \mathrm{x}-0.00057 \mathrm{x}^{2}\left(R^{2}=0.64\right) ; 112 \mathrm{~N}-224 \mathrm{~K}, \mathrm{y}=0.033+0.0144 \mathrm{x}-$ $0.00038 \mathrm{x}^{2}\left(R^{2}=0.66\right) ; 168 \mathrm{~N}-224 \mathrm{~K}, \mathrm{y}=0.034+0.014 \mathrm{x}-0.0003 \mathrm{x}^{2}\left(R^{2}=0.72\right)$; $196 \mathrm{~N}-280 \mathrm{~K}, \mathrm{y}=0.040+0.0073 \mathrm{x}-0.00015 \mathrm{x}^{2}\left(R^{2}=0.52\right)$. rate. However, despite the significant delay in flowering from $168 \mathrm{~N}-224 \mathrm{~K}$ fertigation, the relative rates of male and female flower production were similar to those with $112 \mathrm{~N}-112 \mathrm{~K}$, indicating that once flowering was initiated, further flower development was not inhibited by high $\mathrm{N}-\mathrm{K}$ fertigation rates. This effect did not carry over to the low $\mathrm{N}$ fertigation regime, where the relative rates of male and female flower production were markedly decreased by fertigation of $56 \mathrm{~N}-112 \mathrm{~K}$.

Regression analysis of daily female flower production on days after initial anthesis showed a quadratic pattern of flower development in each treatment (Fig. 1). The period of highest female flower production in the $112 \mathrm{~N}-112 \mathrm{~K}$ and $112 \mathrm{~N}-224 \mathrm{~K}$ treatments occurred 15 and 19 days after initial anthesis, or $\approx 65$ and 69 DAS, respectively. In both the dry-blend and $168 \mathrm{~N}-224 \mathrm{~K}$ treatments, peak female flower production occurred later in the season, $\approx 23$ days after initial anthesis, or 76 and 79 DAS, respectively. The relationship between daily male flower production and days after initial anthesis was generally linear, with the number of staminate flowers produced per day increasing as days after initial anthesis increased (Fig. 2). In several of the treatments, a stair-step pattern in male flower development was observed, particularly in 1987. Although the exact nature of this response is not clear, it appeared that this pattern was most prevalent later in the season when the production of staminate flowers was highest, indicating that a heavy flower load may have been a contributing factor. The relatively flat slope of the $56 \mathrm{~N}-112 \mathrm{~K}$ regression line in 1987 for female flowers, and the stair-step response in male flowers with $56 \mathrm{~N}-112 \mathrm{~K}$ and $112 \mathrm{~N}-56 \mathrm{~K}$, suggested that plants in these treatments were having difficulty producing flowers.

Fruit set. With the exception of the low $\mathrm{N}$ fertigation treatment $(56 \mathrm{~N}-112 \mathrm{~K})$, fruit set was not significantly affected by $\mathrm{N}-\mathrm{K}$ fertilization regime (Table 2). Failure of most early flowers to set fruit was generally attributable to poor pollination due to unfavorable weather conditions (cool temperatures and cloudy overcast days) during anthesis (Jaycox, 1978). The relatively high level of fruit set in both the dry-blend and $168 \mathrm{~N}-224 \mathrm{~K}$ fertigation treatments indicated that high initial $\mathrm{N}$ rates did not have an adverse effect on early fruit development. The low percentage of fruit set in the $56 \mathrm{~N}-112 \mathrm{~K}$ treatment most likely reflected the poor condi- 

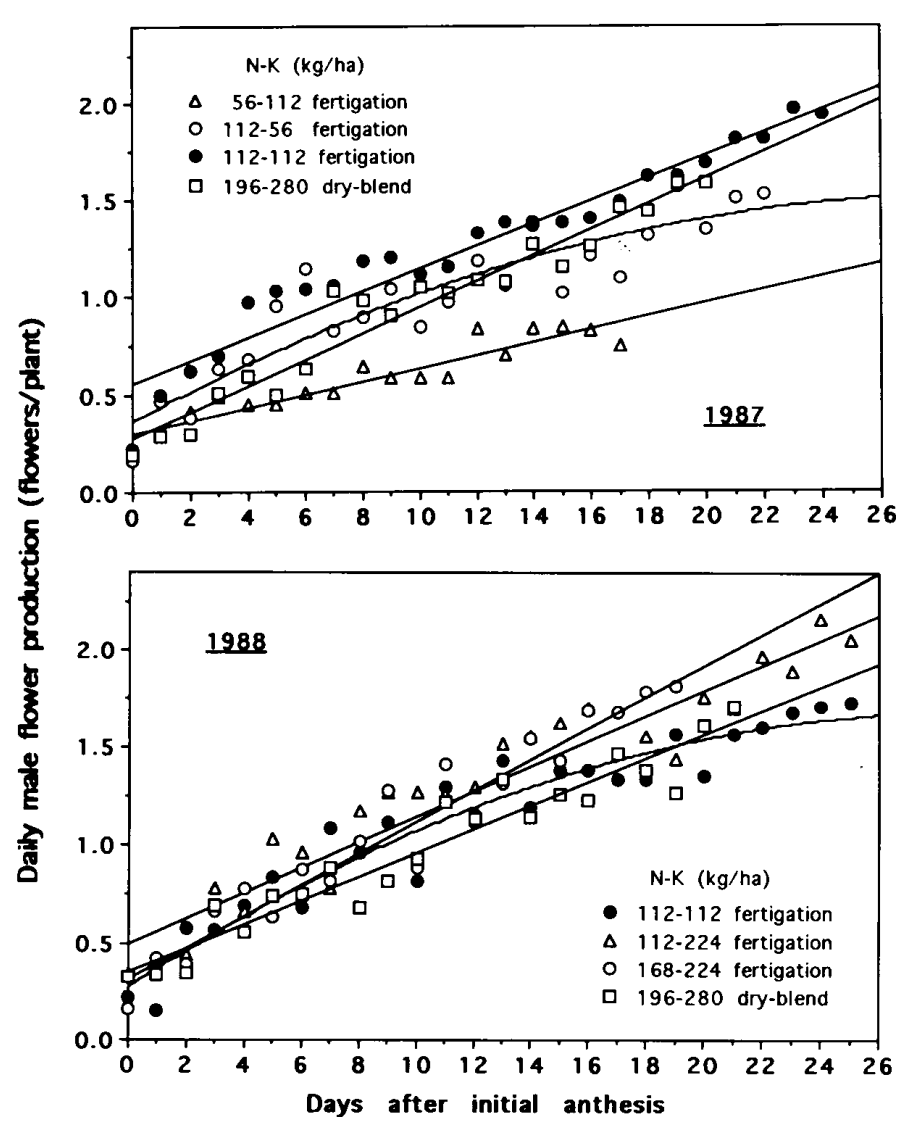

Fig. 2. Relationship between daily male flower production and days after initial anthesis, in response to various $\mathrm{N}-\mathrm{K}$ fertilization regimes in 1987 and 1988 . Regression equations for the lines shown were as follows. 1987-56N-112K, y $=0.314+0.0271 \mathrm{x}\left(R^{2}=0.67\right) ; 112 \mathrm{~N}-56 \mathrm{~K}, \mathrm{y}=0.369+0.0773 \mathrm{x}-0.00128 \mathrm{x}^{2}\left(R^{2}\right.$ $=0.70) ; 112 \mathrm{~N}-112 \mathrm{~K}, \mathrm{y}=0.559+0.0586 \mathrm{x}\left(R^{2}=0.76\right) ; 196 \mathrm{~N}-280 \mathrm{~K}, \mathrm{y}=0.271+$ $0.068 \mathrm{x}\left(R^{2}=0.82\right) ; 1988-112 \mathrm{~N}-112 \mathrm{~K}, \mathrm{y}=0.294+0.0895 \mathrm{x}-0.0013 \mathrm{x}^{2}\left(R^{2}=\right.$ $0.80) ; 112 \mathrm{~N}-224 \mathrm{~K}, \mathrm{y}=0.473+0.0681 \mathrm{x}\left(R^{2}=0.80\right) ; 168 \mathrm{~N}-224 \mathrm{~K}, \mathrm{y}=0.296+$ $0.853 \mathrm{x}\left(R^{2}=0.78\right) ; 196 \mathrm{~N}-280 \mathrm{~K}, \mathrm{y}=0.354+0.0607 \mathrm{x}\left(R^{2}=0.68\right)$.

tion of the plants at the low $\mathrm{N}$ fertigation rate.

Growth response and tissue nutrient concentration. Highest vine dry weights and stem lengths at 72 DAS occurred with either $168 \mathrm{~N}-224 \mathrm{~K}$ fertigation or $196 \mathrm{~N}-280 \mathrm{~K}$ dry-blend application (Table 3). In both years, vine dry-matter production and stem elongation increased as the fertigated $\mathrm{N}$ fraction increased, with relatively little effect from the fertigated K component. Seedlings fertigated with $56 \mathrm{~N}-112 \mathrm{~K}$ were mildly chlorotic almost from the start, and by 72 DAS plant growth was clearly stunted. There was no field indication of excessive vegetative growth in any of the fertigation treatments. Analysis of pumpkin growth components showed that the increased growth response with $168 \mathrm{~N}-224 \mathrm{~K}$ fertigation was due to an increase in the number of nodes, whereas in the $196 \mathrm{~N}-$ $280 \mathrm{~K}$ dry-blend treatment, enhanced vine growth resulted from increases in both node number and internode length.

Similar to the response in the various growth parameters, leaf $\mathrm{N}$ concentrations generally increased with increasing $\mathrm{N}$ fertigation rate, with little effect from fertigated $\mathrm{K}$ (Table 4 ). In both years, leaf $\mathrm{N}$ concentrations at $46 \mathrm{DAS}$ were highest with the dry-blend application, but by $72 \mathrm{DAS}$, tissue $\mathrm{N}$ levels were comparable in the dry-blend treatment and several of the fertigation treatments. Although $\mathrm{K}$ fertigation had little influence on vine growth, leaf $\mathrm{K}$ content at each sampling date increased as $\mathrm{K}$ fertigation rate increased. In each treatment, leaf $\mathrm{N}$ and $\mathrm{K}$ levels tended to decrease as the season progressed, with the largest reductions occurring with the dry-blend application. By 90 DAS, leaf N and K concentrations were greater with $112 \mathrm{~N}-112 \mathrm{~K}$ fertigation than with the dry-blend application, and were within the general ranges previously reported for pumpkins on irrigated soil (Swiader, 1985).

Yield response. Highest yields of early-set marketable fruit (fruits that set before 65 DAS) were obtained with fertigation of $112 \mathrm{~N}$, in combination with either 112 or $224 \mathrm{~K}$; the small yield decrease with $112 \mathrm{~N}-56 \mathrm{~K}$ relative to $112 \mathrm{~N}-112 \mathrm{~K}$ in 1987 was significant at the $10 \%$ level of probability (Table 5). Although there was a statistically significant increase in the average size $(\mathrm{kg} /$ fruit) of early set fruit with the dry-blend application vs. several of the fertigation treatments, in most cases this increase was of minor practical importance. Fertigation of either $56 \mathrm{~N}-112 \mathrm{~K}$ or $168 \mathrm{~N}-$ $224 \mathrm{~K}$ decreased the yield and number of early set fruit significantly. The notably large size of early set pumpkins in the $56 \mathrm{~N}-$ $112 \mathrm{~K}$ treatment reflected the very small fruit load that developed at the low $\mathrm{N}$ fertigation rate (Brinen et al., 1979). Overall, yields of early set fruit accounted for $47 \%$ of the total marketable weight produced with $112 \mathrm{~N}$ (data pooled over $\mathrm{K}$ fertigation rates), $39 \%$ with the $196 \mathrm{~N}-280 \mathrm{~K}$ dry-blend application, and $\approx 24 \%$ with either $168 \mathrm{~N}-224 \mathrm{~K}$ or $56 \mathrm{~N}-112 \mathrm{~K}$.

Mid-season fruit production (represented by pumpkins set after 64 DAS, and which were ripe at harvest) was similar in both years in the $112 \mathrm{~N}-112 \mathrm{~K}$ fertigation and the dry-blend treatments (Table 5). Fertigating $56 \mathrm{~N}-112 \mathrm{~K}, 112 \mathrm{~N}-56 \mathrm{~K}$, or $168 \mathrm{~N}-224 \mathrm{~K}$ decreased the yield of mid-season-set fruit, but had little effect on fruit number. The concomitant reduction in fruit size and total yield of mid-season-set pumpkins with $112 \mathrm{~N}-56 \mathrm{~K}$, coupled with the rela-

Table 3. Effect of $\mathrm{N}-\mathrm{K}$ fertilization regime on pumpkin vegetative growth components at 72 days after seeding (DAS) in 1987 and 1988.

\begin{tabular}{|c|c|c|c|c|}
\hline $\begin{array}{l}\text { N-K fertilization } \\
\left(\mathrm{kg} \cdot \mathrm{ha}^{-1}\right)\end{array}$ & $\begin{array}{l}\text { Vine dry wt } \\
\text { (g/plant) }\end{array}$ & $\begin{array}{l}\text { Vine stem length } \\
\qquad(\mathrm{cm})\end{array}$ & $\begin{array}{c}\text { Vine } \\
\text { node no. }\end{array}$ & $\begin{array}{l}\text { Avg node length } \\
(\mathrm{cm})\end{array}$ \\
\hline \multicolumn{5}{|c|}{1987} \\
\hline 56-112 Fertigation & $100 \mathrm{c}^{\mathrm{z}}$ & $171.5 \mathrm{c}$ & $25.0 \mathrm{c}$ & $6.8 \mathrm{~b}$ \\
\hline 112-56 Fertigation & $241 \mathrm{~b}$ & $307.8 \mathrm{~b}$ & $38.5 \mathrm{~b}$ & $8.0 \mathrm{ab}$ \\
\hline $112-112$ Fertigation & $271 b$ & $325.0 \mathrm{~b}$ & $42.8 \mathrm{ab}$ & $7.6 \mathrm{~b}$ \\
\hline 196-280 Dry-blend & $357 \mathrm{a}$ & $\begin{array}{l}468.1 \mathrm{a} \\
1988\end{array}$ & $48.8 \mathrm{a}$ & $9.6 \mathrm{a}$ \\
\hline 112-112 Fertigation & $316 b$ & $409.0 \mathrm{~b}$ & $46.5 \mathrm{~b}$ & $8.8 \mathrm{~b}$ \\
\hline 112-224 Fertigation & $339 \mathrm{~b}$ & $459.7 \mathrm{~b}$ & $50.0 \mathrm{~b}$ & $9.2 \mathrm{ab}$ \\
\hline 168-224 Fertigation & $420 \mathrm{a}$ & $558.5 \mathrm{a}$ & $62.0 \mathrm{a}$ & $9.0 \mathrm{ab}$ \\
\hline 196-280 Dry-blend & $481 \mathrm{a}$ & $611.8 \mathrm{a}$ & $58.3 \mathrm{a}$ & $10.5 \mathrm{a}$ \\
\hline
\end{tabular}

${ }^{\mathrm{z}}$ For each year, mean separation within columns by LSD at $P=0.05$. 
Table 4. Effect of $\mathrm{N}-\mathrm{K}$ fertilization regime on pumpkin leaf $\mathrm{N}$ and $\mathrm{K}$ concentrations at 46, 72, and 90 days after seeding (DAS) in 1987 and 1988.

\begin{tabular}{|c|c|c|c|c|c|c|}
\hline \multirow{2}{*}{$\begin{array}{l}\text { N-K fertilization } \\
\left(\mathrm{kg} \cdot \mathrm{ha}^{-1}\right)\end{array}$} & \multicolumn{3}{|c|}{ Leaf $N(\%$ dry wt) } & \multicolumn{3}{|c|}{ Leaf $\mathrm{K}(\%$ dry wt) } \\
\hline & 46 DAS & 72 DAS & 90 DAS & 46 DAS & 72 DAS & $90 \mathrm{DAS}$ \\
\hline \multicolumn{7}{|c|}{1987} \\
\hline 56-112 Fertigation & $2.48 c^{2}$ & $2.27 \mathrm{~b}$ & $1.83 \mathrm{c}$ & $3.12 \mathrm{~b}$ & $3.00 \mathrm{a}$ & $2.85 \mathrm{a}$ \\
\hline $112-56$ Fertigation & $4.24 \mathrm{~b}$ & $4.03 \mathrm{a}$ & $3.37 \mathrm{a}$ & $2.70 \mathrm{c}$ & $2.48 \mathrm{~b}$ & $2.20 \mathrm{~b}$ \\
\hline 112-112 Fertigation & $4.11 \mathrm{~b}$ & $3.83 \mathrm{a}$ & $3.66 \mathrm{a}$ & $3.50 \mathrm{ab}$ & $3.38 \mathrm{a}$ & $2.98 \mathrm{a}$ \\
\hline 196-280 Dry-blend & $4.79 \mathrm{a}$ & $4.17 \mathrm{a}$ & $\begin{array}{c}2.98 \mathrm{~b} \\
1988\end{array}$ & $3.82 \mathrm{a}$ & $3.44 \mathrm{a}$ & $2.35 \mathrm{~b}$ \\
\hline 112-112 Fertigation & $4.20 \mathrm{~b}$ & $3.71 \mathrm{~b}$ & $3.23 \mathrm{~b}$ & $4.00 \mathrm{~b}$ & $3.52 \mathrm{~b}$ & $3.18 \mathrm{~b}$ \\
\hline 112-224 Fertigation & $4.33 \mathrm{~b}$ & $4.00 \mathrm{~b}$ & $3.40 \mathrm{~b}$ & $4.58 \mathrm{a}$ & $4.22 \mathrm{a}$ & $3.60 \mathrm{a}$ \\
\hline 168-224 Fertigation & $4.55 \mathrm{~b}$ & $4.58 \mathrm{a}$ & $4.11 \mathrm{a}$ & $4.12 \mathrm{ab}$ & $3.75 \mathrm{ab}$ & $3.72 \mathrm{a}$ \\
\hline 196-280 Dry-blend & $5.26 \mathrm{a}$ & $4.16 \mathrm{ab}$ & $2.64 \mathrm{c}$ & $4.70 \mathrm{a}$ & $3.88 \mathrm{ab}$ & $2.68 \mathrm{c}$ \\
\hline
\end{tabular}

${ }^{\mathrm{z}}$ For each year, mean separation within columns by LSD at $P=0.05$.

Table 5. Effect of N-K fertilization regime on pumpkin marketable fruiting response and cull production in 1987 and 1988.

\begin{tabular}{|c|c|c|c|c|c|c|c|c|c|c|c|c|}
\hline \multirow[b]{2}{*}{$\begin{array}{l}\mathrm{N}-\mathrm{K} \text { fertilization } \\
\left(\mathrm{kg} \cdot \mathrm{ha}^{-1}\right)\end{array}$} & \multicolumn{3}{|c|}{$\begin{array}{c}\text { Early set } \\
\text { marketable fruit }\end{array}$} & \multicolumn{3}{|c|}{$\begin{array}{l}\text { Mid-season-set } \\
\text { marketable fruit }\end{array}$} & \multicolumn{3}{|c|}{ Usable green fruit ${ }^{\mathrm{x}}$} & \multicolumn{2}{|c|}{$\begin{array}{c}\text { Total } \\
\text { marketable yield }\end{array}$} & \multirow[b]{2}{*}{$\begin{array}{c}\text { Culls } \\
(\%)\end{array}$} \\
\hline & $\begin{array}{l}\text { Yield } \\
\left(\mathrm{t} \cdot \mathrm{ha}^{-1}\right)\end{array}$ & $\begin{array}{c}\text { Fruit } \\
\text { (no./ha) }\end{array}$ & $\begin{array}{c}\mathrm{Wt} \\
\text { (kg/fruit) }\end{array}$ & $\begin{array}{l}\text { Yield } \\
\left(\mathrm{t} \cdot \mathrm{ha}^{-1}\right)\end{array}$ & $\begin{array}{c}\text { Fruit } \\
\text { (no./ha) }\end{array}$ & $\begin{array}{c}\mathrm{Wt} \\
\text { (kg/fruit) }\end{array}$ & $\begin{array}{l}\text { Yield } \\
\left(\mathrm{t} \cdot \mathrm{ha}^{-1}\right)\end{array}$ & $\begin{array}{c}\text { Fruit } \\
\text { (no./ha) }\end{array}$ & $\begin{array}{c}\mathrm{Wt} \\
\text { (kg/fruit) }\end{array}$ & $\begin{array}{l}\text { Yield } \\
\left(\mathrm{t} \cdot \mathrm{ha}^{-1}\right)\end{array}$ & $\begin{array}{c}\text { Fruit } \\
\text { (no./ha) }\end{array}$ & \\
\hline \multicolumn{13}{|c|}{1987} \\
\hline 56-112 Fertigation & $9.3 c^{w}$ & $1129 \mathrm{c}$ & $8.18 \mathrm{a}$ & $18.3 \mathrm{~b}$ & 3919 a & $4.69 \mathrm{~b}$ & $9.6 \mathrm{~b}$ & $2125 \mathrm{~b}$ & $4.54 \mathrm{a}$ & $37.3 \mathrm{c}$ & $7173 \mathrm{c}$ & $5.4 \mathrm{~b}$ \\
\hline 112-56 Fertigation & $34.2 \mathrm{a}$ & $5844 \mathrm{a}$ & $5.85 \mathrm{c}$ & $22.0 \mathrm{~b}$ & $4516 \mathrm{a}$ & $4.87 \mathrm{~b}$ & $11.5 \mathrm{ab}$ & 2749 a & $4.19 \mathrm{a}$ & $67.7 \mathrm{~b}$ & $13109 \mathrm{a}$ & $9.7 \mathrm{a}$ \\
\hline 112-112 Fertigation & $39.5 \mathrm{a}$ & $6376 a$ & $6.17 \mathrm{c}$ & $27.4 \mathrm{a}$ & $4051 \mathrm{a}$ & $6.75 \mathrm{a}$ & $15.0 \mathrm{a}$ & $3370 \mathrm{a}$ & $4.46 \mathrm{a}$ & $81.9 \mathrm{a}$ & $13797 \mathrm{a}$ & $11.0 \mathrm{a}$ \\
\hline 196-280 Dry-blend & $24.5 \mathrm{~b}$ & $3653 \mathrm{~b}$ & $6.73 \mathrm{~b}$ & $32.5 \mathrm{a}$ & $\begin{array}{r}4583 \mathrm{a} \\
1988\end{array}$ & $7.08 \mathrm{a}$ & $6.5 \mathrm{c}$ & $1303 \mathrm{c}$ & $5.01 \mathrm{a}$ & $63.5 \mathrm{~b}$ & $9539 \mathrm{~b}$ & $3.6 \mathrm{~b}$ \\
\hline 112-112 Fertigation & $46.8 \mathrm{a}$ & 7239 a & $6.46 \mathrm{~b}$ & $32.6 \mathrm{ab}$ & 4716 a & $6.91 \mathrm{a}$ & $19.1 \mathrm{~b}$ & $3553 \mathrm{~b}$ & $5.36 \mathrm{~b}$ & $98.6 \mathrm{a}$ & $15508 \mathrm{a}$ & $13.3 \mathrm{~b}$ \\
\hline 112-224 Fertigation & $40.6 \mathrm{a}$ & $6110 a$ & $6.64 \mathrm{~b}$ & $35.3 \mathrm{a}$ & $5048 \mathrm{a}$ & $7.00 \mathrm{a}$ & $21.3 \mathrm{~b}$ & $3686 \mathrm{~b}$ & $5.79 a b$ & $97.3 \mathrm{a}$ & $14844 \mathrm{a}$ & $14.8 \mathrm{~b}$ \\
\hline 168-224 Fertigation & $18.7 \mathrm{c}$ & 2989 c & $6.31 \mathrm{~b}$ & $27.8 \mathrm{~b}$ & $4151 \mathrm{a}$ & $6.71 \mathrm{a}$ & $33.0 \mathrm{a}$ & $6708 \mathrm{a}$ & $4.92 \mathrm{~b}$ & $79.5 \mathrm{~b}$ & $13848 \mathrm{ab}$ & $22.1 \mathrm{a}$ \\
\hline 196-280 Dry-blend & $30.8 \mathrm{~b}$ & $4284 \mathrm{~b}$ & $7.18 \mathrm{a}$ & $36.2 \mathrm{a}$ & $4815 \mathrm{a}$ & $7.53 \mathrm{a}$ & $10.6 \mathrm{c}$ & $1760 \mathrm{c}$ & $6.02 \mathrm{a}$ & $77.6 \mathrm{~b}$ & $10859 \mathrm{~b}$ & $6.2 \mathrm{c}$ \\
\hline
\end{tabular}

${ }^{\mathrm{z}}$ Fruit that set by 64 days after seeding (DAS).

${ }^{\mathrm{y}}$ Fruit that set after 64 DAS, and which was ripe (mature) at harvest.

${ }^{x}$ Usable immature fruit $>15 \mathrm{~cm}$ in diameter (suitable for mechanical harvest and processing).

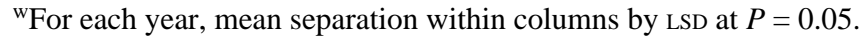

tively high number of fruit, indicated that plants in this treatment had difficulty supporting a full fruit load later in the season.

Usable green and cull fruit production tended to increase with increasing $\mathrm{N}$ fertigation rate, and to a lesser degree with increasing $\mathrm{K}$ fertigation rate (Table 5 ). Immature fruit accounted for $\approx 42 \%$ of the total marketable fruit weight produced in the $168 \mathrm{~N}-224 \mathrm{~K}$ fertigation treatment, compared to $12 \%$ with the dry-blend application, and $20 \%$ with fertigation of either $112 \mathrm{~N}-112 \mathrm{~K}$ or 112 $224 \mathrm{~K}$ (data averaged over treatments). Presumably, most of the usable green fruit produced at the high $\mathrm{N}-\mathrm{K}$ fertigation rate consisted of the delayed set of primary fruit, whereas, in the other treatments, it most likely represented a second set of fruit that plants were able to maintain after development of the initial set (Whitaker and Davis, 1962). Cull production was composed mainly of immature pumpkins that were unsuitable for mechanical harvest and processing due to their small size ( $<15 \mathrm{~cm}$ in diameter). Some cull production was also the result of fruit cracking, primarily on the larger ripe fruits. These latter defects were most prevalent with fertigation of $112 \mathrm{~N}$ or $168 \mathrm{~N}$, which agrees with earlier reports for cantaloupes where high irrigation and $\mathrm{N}$ rates increased the incidence of culls associated with cracking and splitting of larger fruits (Flocker et al., 1965).

Total marketable yields were highest with either $112 \mathrm{~N}-112 \mathrm{~K}$ or $112 \mathrm{~N}-224 \mathrm{~K}$ (Table 5). Due to the stimulation of usable-green fruit at the high $\mathrm{N}-\mathrm{K}$ fertigation rate, total marketable fruit weight in 1988 was comparable in the $168 \mathrm{~N}-224 \mathrm{~K}$ fertigation and the dryblend treatments. Since laboratory results showed no differences in pumpkin soluble solids due to $\mathrm{N}-\mathrm{K}$ fertility treatments for any fruit maturity period (data not shown), the increases in total marketable yield with either $112 \mathrm{~N}-112 \mathrm{~K}$ or $112 \mathrm{~N}-224 \mathrm{~K}$ fertigation were attributed to a greater number of marketable fruit, rather than significantly larger fruit size ( $\mathrm{kg} /$ fruit) or differences in fruit composition.

This 2-year study demonstrates the importance of applying adequate rates of fertigated $\mathrm{N}$ early in the season to promote timely flower production and obtain high yields of early set pumpkins on sandy soil. Because this study was not a complete factorial experiment, it was not possible to clearly separate the main effects of $\mathrm{N}$ and $\mathrm{K}$ fertigation, or their interactions, on flower and fruit development. Nevertheless, for the levels and timing of $\mathrm{N}$ and $\mathrm{K}$ used here, fertigated $\mathrm{K}$ did not appear as critical for early flowering and fruiting as fertigated $\mathrm{N}$.

As shown by these findings, $\mathrm{K}$ nutrition may become a limiting factor later in the season, especially under a heavy fruit load. Fertigation of $56 \mathrm{~K}$, in combination with $112 \mathrm{~N}$, was insufficient for fruits set after 64 DAS to reach their full potential by harvest. Although there was no indication of excessive vegetative growth or a reduction in either the relative rate of flowering or fruit set with 
$168 \mathrm{~N}-224 \mathrm{~K}$, delayed flowering at the high $\mathrm{N}-\mathrm{K}$ fertigation rate did not allow sufficient time for fruit ripening, resulting in high amounts of immature fruit at harvest. Sprinkler-applied 112N$112 \mathrm{~K}$ split into five fertigations during the growing season (supplemented with a preplant dry-blend application of $28 \mathrm{~N}-56 \mathrm{~K}$ ) produced high yields without compromising early fruit maturity. Dryblend application of $196 \mathrm{~N}-280 \mathrm{~K}$ decreased early and total yields significantly.

These results indicate that effective $\mathrm{N}-\mathrm{K}$ fertigation for pumpkin production on sandy soil would be at considerably lower rates than current dry-blend fertilization practices. Properly managed, $\mathrm{N}-\mathrm{K}$ fertigation should reduce ground water pollution, particularly with nitrates, without jeopardizing pumpkin yields. Different rates and timings of fertigated $\mathrm{N}-\mathrm{K}$ than those evaluated here may further enhance early and total pumpkin yields.

\section{Literature Cited}

Brinen, G.H. , S.J. Locascio, and G.W. Elmstrom. 1979. Plant and row spacing, mulch and fertilizer rate effects on watermelon production. J. Amer. Soc. Hort. Sci. 104:724-726.

Cataldo, D.A., L.E. Schrader, and V.L. Young. 1974. Analysis by digestion and colorimetric assay of total nitrogen in plant tissues high in nitrate. Crop Sci. 14:854-856.

Flocker, W.J., J.C. Lingle, R.M. Davis, and R.J. Miller. 1965. Influence of irrigation and nitrogen fertilization on yield, quality, and size of cantaloupes. Proc. Amer. Soc. Hort. Sci. 86:424-432.

Jaycox, E.R. 1978. Pollination of fresh vegetables and canning crops. In: J.W. Courter (ed.). Proceedings 1978 Illinois vegetable growers schools. Univ. Ill. Coop. Ext. Serv.

Nelson, D.W. and L.E. Sommers. 1980. Total nitrogen analysis of soil and plant tissues. J. Assn. Offic. Anal. Chem. 63:770-778.

Rehm, G.W. and R.A. Wiese. 1975. Effect of method of nitrogen application on corn (Zea mays L.) grown on irrigated sandy soils. Soil Sci. Soc. Amer. Proc. 39:1217-1220.

Saffinga, P.G. and D.R. Keeney. 1977. Nitrogen and chloride uptake by irrigated Russet Burbank potatoes. Agron. J. 69:258-264.

Smittle, D.A. and E.D. Threadgill. 1982. Response of squash to irrigation, nitrogenfertilization, and tillage systems. J. Amer. Soc. Hort. Sci. 107:437-440.

Spector, P.C., J.H. Goodnight, J.P. Sall, and W.S. Sarle. 1985. The GLM procedure. In: A.A. Ray (ed.). SAS user's guide: Statistics. SAS Inst., Cary, N.C. p. 433-506.

Swiader, J.M., J.G. Sullivan, F.G. Freiji, and J.A. Grunau. 1988. Nitrate monitoring for pumpkin production on dryland and irrigated soil. J. Amer. Soc. Hort. Sci. 113:684-689.

Swiader, J.M. 1985. Seasonal growth and composition and accumulation of N-P-K in dryland and irrigated pumpkins. J. Plant Nutr. 8:909-919.

Watts, D.A. and D.C. Martin. 1981. Effects of water and nitrogen management on nitrate leaching loss from sand. Trans. Amer. Soc. Agr. Eng. 4:911-916.

Whitaker, T.W. and G.N. Davis. 1962. Cucurbits. Leonard Hill Interscience, New York. 